\title{
BADANIA NOŚNOŚCI MOBILNYCH POKRYĆ KOMPOZYTOWYCH STOSOWANYCH DO ODBUDOWY NAWIERZCHNI LOTNISKOWYCH
}

\begin{abstract}
Sprawna odbudowa zniszczeń nawierzchni lotniskowych umożliwia wznowienie wykonywania operacji lotniczych w czasie możliwie najkrótszym. Dotychczasowe metody i technologie odbudowy nawierzchni lotniskowych, zniszczonych w sytuacjach losowych (zagrożenia wojennego), nie były w stanie sprostać wysokim reżimom czasowym, dlatego skonstruowano mobilne, kompozytowe nawierzchnie lotniskowe. W publikacji przedstawione zostaną walory eksploatacyjne i użytkowe elastycznego pokrycia lotniskowego ELP-1 KRATER, którego producentem jest Stocznia Żuławy. Zaprezentowana zostanie struktura modelu obliczeniowego konstrukcji składającej się z nawierzchni kompozytowej i podłoża gruntowego, a także wyniki badań poligonowych, które zostały przeprowadzone przez Instytut Techniczny Wojsk Lotniczych. Ponadto, omówione zostaną wyniki badań nośności kompozytowego pokrycia lotniskowego ELP-1 KRATER uzyskane w trakcie weryfikacji poligonowej.
\end{abstract}

Słowa kluczowe: kompozytowe pokrycie lotniskowe, przenośne nawierzchnie lotniskowe, odbudowa zniszczeń lotniskowych, nośność nawierzchni lotniskowych

\section{Wprowadzenie}

Ostatnie konflikty zbrojne, które miały miejsce na Falklandach, w Zatoce Perskiej, Iraku, jak również trwająca obecnie misja sił NATO w Afganistanie, potwierdziły zasadność stosowania mobilnych, składanych nawierzchni lotniskowych. W ramach prowadzonej działalności badawczo-rozwojowej, Instytut Techniczny Wojsk Lotniczych (ITWL) przeprowadził szczegółowe badania laboratoryjne i poligonowe mobilnego pokrycia kompozytowego ELP-1 KRATER, które zostało wyprodukowane w Polsce przez Stocznię Żuławy.

Wykorzystanie przedmiotowego pokrycia kompozytowego pozwala na spełnienie wysokich reżimów czasowych i zapewnienie bezpieczeństwa dla poruszających się po nich statków powietrznych. Pokrycia te mogą również znaleźć zastosowanie w sytuacjach kryzysowych poza granicami Polski, np. w ramach kontyn-

\footnotetext{
${ }^{1}$ Mariusz Wesołowski, Instytut Techniczny Wojsk Lotniczych, ul. Księcia Bolesława 6, 01-494 Warszawa, 261851 324, mariusz.wesolowski@itwl.pl
} 
gentów wojskowych. Podobne rozwiązania funkcjonują w innych krajach, między innymi w Stanach Zjednoczonych, Niemczech czy Francji.

\section{Pokrycie kompozytowe ELP-1 KRATER}

Mobilne, kompozytowe pokrycie lotniskowe ELP-1 KRATER składa się z 9 elementów, z których każdy posiada wymiary: szerokość 1,8 m, długość 9,1 m i grubość $8,0 \mathrm{~mm}$. Elementy połączone są ze sobą elastycznymi przegubami, które zapewniają współpracę pojedynczych segmentów pod obciążeniem. Zespół tych elementów stanowi pokrycie o wymiarach: 16,5 x 9,1 m. Połączone ze sobą dwa pokrycia tworzą matę o wymiarach: 16,5 x 18,2 m, która spełnia wymagania naprawy dużych uszkodzeń nawierzchni lotniskowych. Standardowe pokrycie kompozytowe ELP-1 KRATER (rys. 1) waży 1638 kg [3].

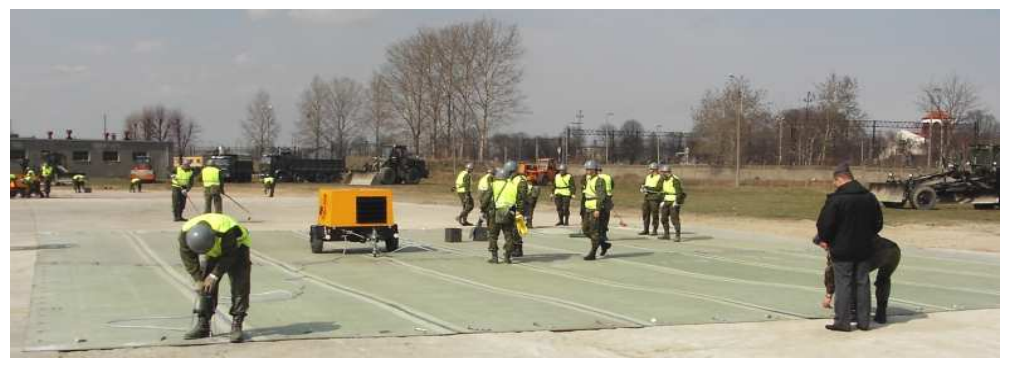

Rys. 1. Mata kompozytowa ELP-1 KRATER

Fig. 1. The ELP-1 KRATER composite mat

\subsection{Składniki materiałowe, struktura i technologia produkcji}

Do produkcji krajowej, mobilnej nawierzchni lotniskowej wykorzystano jako matrycę żywicę poliestrową typu PALATAL U 541 TV-03, a jako wzmocnienie włókno szklane typu E. Producent w przeprowadzonych przez siebie badaniach kompozytu uzyskał następujące wyniki badań wytrzymałościowych, które przedstawiono w tabeli 1 .

Tabela 1. Własności kompozytu

Table 1. Composite properties

\begin{tabular}{|l|r|c|}
\hline \multicolumn{1}{|c|}{ Własności kompozytu } & Wartość & Jednostka \\
\hline Wytrzymałość na rozciąganie & 145,00 & $\mathrm{MPa}$ \\
\hline Wytrzymałość na zginanie & 205,00 & $\mathrm{MPa}$ \\
\hline Moduł sprężystości przy statycznym rozciąganiu & 12,20 & $\mathrm{GPa}$ \\
\hline Moduł sprężystości przy zginaniu & 8,95 & $\mathrm{GPa}$ \\
\hline Współczynnik Poissona & 0,29 & --- \\
\hline
\end{tabular}


Struktura wyprodukowanego kompozytu składa się z dziesięciu warstw maty z włókna szklanego oraz dwóch warstw tkaniny. Produkcja odbywała się na specjalnie przygotowanych stanowiskach roboczych, gdzie pojedyncze warstwy, z których składa się struktura płyty łączono na zakład z elastycznym łącznikiem płyt. Wytworzony kompozyt miał za zadanie spełnienie specjalnych wymagań technicznych i użytkowych. Decydującymi cechami były: zdolność do przenoszenia obciążeń statycznych, dynamicznych i termicznych od poruszających się po tych nawierzchniach statków powietrznych. W związku z powyższym, pokrycie lotniskowe ELP-1 KRATER zostało zweryfikowane podczas badań przeprowadzonych w warunkach laboratoryjnych i poligonowych.

\subsection{Badania materiałowe}

Mobilne, kompozytowe pokrycie lotniskowe ELP-1 KRATER zostało poddane szczegółowym badaniom materiałowym, w celu określenia podstawowych własności fizyko-mechanicznych oraz sprawdzenia jego odporności na działanie czynników chemicznych występujących na nawierzchniach lotniskowych podczas ich całorocznej eksploatacji [1], [2]. Badania wykonano w laboratoriach Zakładu Lotniskowego oraz Zakładu Niezawodności i Bezpieczeństwa Techniki Lotniczej ITWL, a także w laboratorium badań materiałowych Wojskowej Akademii Technicznej (WAT). Zakres badań laboratoryjnych obejmował: określenie wytrzymałości na rozciąganie, sprawdzenie wytrzymałości na zginanie, sprawdzenie wytrzymałości zmęczeniowej na zginanie, badania wytrzymałościowe w podwyższonych i niskich temperaturach, sprawdzenie odporności na działanie czynników eksploatacyjnych, badanie szorstkości (średnia wartość współczynnika tarcia wynosi 0,52 ), oznaczenie wytrzymałości elastycznych połączeń między elementami pokrycia lotniskowego ELP-1 KRATER oraz badanie wytrzymałości połączeń kotwiących pokrycie do nawierzchni lotniskowej (połączenia śrubowe).

Wyniki uzyskane ze zrealizowanego programu badań laboratoryjnych potwierdziły, że kompozyt, z którego wykonano mobilne pokrycie lotniskowe ELP-1 KRATER spełnia zakładane wymagania i może być stosowany do odbudowy zniszczonych nawierzchni lotniskowych, np. drogi startowej.

\section{Badania poligonowe pokrycia kompozytowego ELP-1 KRATER}

Badania poligonowe pokrycia kompozytowego podzielono na trzy etapy. Etap I obejmował badania sprawdzające odbudowę, wypełnienie krateru odpowiednio dobranym kruszywem. Etap II dotyczył badań nośności układu konstrukcyjnego składającego się z pokrycia ELP-1 KRATER i nowo uformowanego podłoża gruntowego. W III etapie badań poligonowych przeprowadzono próby wytrzymałościowe, które polegały na obciążaniu dynamicznym rozłożonego pokrycia. Podczas trwania eksperymentu prowadzony był pomiar sił i odkształceń techniką tensometryczną. Dzięki temu określone zostały między innymi ugięcia pokrycia kompozytowego, siły reakcji w punktach mocowania pokrycia 
do podłoża i siły działające pomiędzy segmentami pokrycia. Wyniki uzyskane $\mathrm{w}$ trakcie weryfikacyjnych badań terenowych, zrealizowanych w ramach pracy [4], będą sukcesywnie prezentowane w kolejnych publikacjach dotyczących pokrycia kompozytowego ELP-1 KRATER.

\subsection{Badania podłoża gruntowego}

Badania odbiorcze nowo uformowanego podłoża gruntowego [4], stanowiącego wypełnienie dużego uszkodzenia typu krater, zostały wykonane z wykorzystaniem lekkiej płyty dynamicznej typu HMP LFG-K, aparatury VSS oraz ciężkiego ugięciomierza udarowego typu HWD. Krater przygotowany na potrzeby badań miał następujące wymiary geometryczne: głębokość leja - 2,5 m; średnica widzialna leja -6,4 m; górna, rzeczywista średnica leja - 11,8 m.

Przy użyciu lekkiej płyty dynamicznej określono moduł dynamiczny $E_{v d}$ dla rodzimego podłoża na dnie krateru $\left(E_{v d}=15,5 \mathrm{MPa}\right)$ oraz dla nowo uformowanego wypełnienia krateru o grubości 2,5 m $\left(E_{v d}=84,9 \mathrm{MPa}\right)$. Kontrolne badanie nośności podłoża gruntowego $\mathrm{w}$ analizowanym kraterze, wykonano przy użyciu urządzenia VSS. Miarą nośności podłoża jest moduł odkształcenia. Liczbowe wielkości uzyskanych wyników wyznaczono z zależności:

$$
E=\frac{3 \cdot \Delta p}{4 \cdot \Delta s} \cdot D
$$

gdzie: $\Delta p$ - przyrost obciążenia jednostkowego w określonym zakresie,

$\Delta s$ - przyrost odkształcenia odpowiadający przyjętemu zakresowi obciążeń jednostkowych, tj. 0,15-0,25 MPa (zakres jak dla warstwy nośnej), $D$ - średnica płyty obciążającej (300 mm).

Przebieg badania $\mathrm{z}$ wykorzystaniem aparatury VSS przedstawiono na rys. 2. Wykorzystując zależność (1) wyznaczono moduły odkształcenia: pierwotny i wtórny

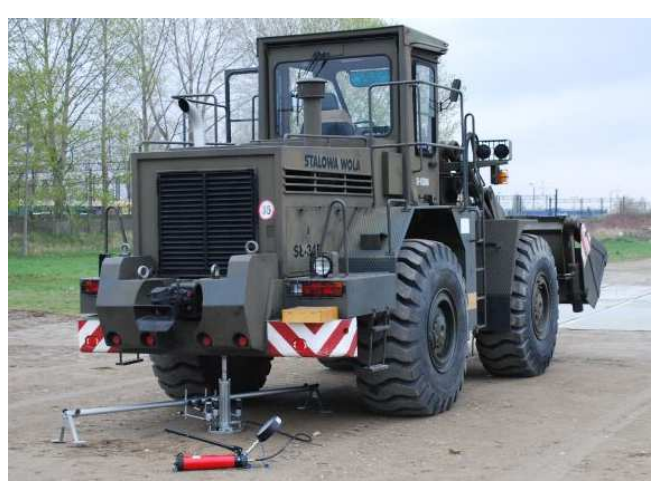
dla podłoża gruntowego $\left(E_{1}\right.$ i $E_{2}$ ) stanowiącego wypełnienie badanego krateru. Wartości wyznaczonych modułów wynoszą odpowiednio: $E_{1}=$ $62,5 \mathrm{MPa}, E_{2}=140,0 \mathrm{MPa}$. $\mathrm{Na}$ podstawie ww. wartości modułów odkształcenia, obliczono wskaźnik odkształce-

Rys. 2. Pomiar modułu odkształcenia podłoża urządzeniem VSS

Fig. 2. Displacement modulus tests with the use of VSS 
nia badanego podłoża gruntowego $I_{o}$, który osiągnął wartość równą 2,2 . Ww. wartości modułów odkształcenia podłoża gruntowego potwierdziły właściwe przygotowanie i zagęszczenie wypełnienia krateru.

Badania nośności podłoża gruntowego, przeprowadzone z wykorzystaniem ciężkiego ugięciomierza udarowego typu HWD potwierdziły dobrą korelację z wynikami uzyskanymi z pomiarów lekką płytą dynamiczną i aparaturą VSS. Zastępczy moduł sprężystości konstrukcji (wypełnienia) odbudowanego krateru wyznaczono na podstawie zależności (2), a jego wartość wyniosła 161,0 MPa.

$$
E_{Z}=\frac{2 \cdot q \cdot a}{u(0)}
$$

gdzie: $E_{z}$ - zastępczy moduł sprężystości konstrukcji pod płytą dociskową, $a$ - promień płyty dociskowej $(150 \mathrm{~mm})$,

$u$ - ugięcie w badanym punkcie $(0$ - pod płytą dociskową),

$q$-naprężenie pod płyta dociskową.

\subsection{Badanie nośności układu konstrukcyjnego}

Badanie nośności układu konstrukcyjnego składającego się z pokrycia kompozytowego ELP-1 KRATER i nowo uformowanego podłoża gruntowego, zostało wykonane $\mathrm{z}$ wykorzystaniem ciężkiego ugięciomierza udarowego typu HWD. Urządzenie działa na zasadzie zrzutu odpowiedniego obciążenia na płytę dociskową z elementem tłumiącym, spoczywającą na badanej nawierzchni (rys.3). W momencie zrzutu czujniki (geofony) umieszczone na listwie oraz pod samą stopą, mierzą wartości ugięcia oraz jego zmianę w czasie. Moduły sprężystości poszczególnych warstw badanego układu konstrukcyjnego, w tym nowo uformowanego wypełnienia krateru, wyznaczone zostały z zależności (2) metodą odwrotną (,backcalculation”). Wartość współczynnika reakcji podłoża $k$ została określona na podstawie [5]. Następnie dokonano iteracyjnego porównywania zmierzonych ugięć i ugięć teoretycznych tak, aby funkcja $F$ miała wartość minimalną:

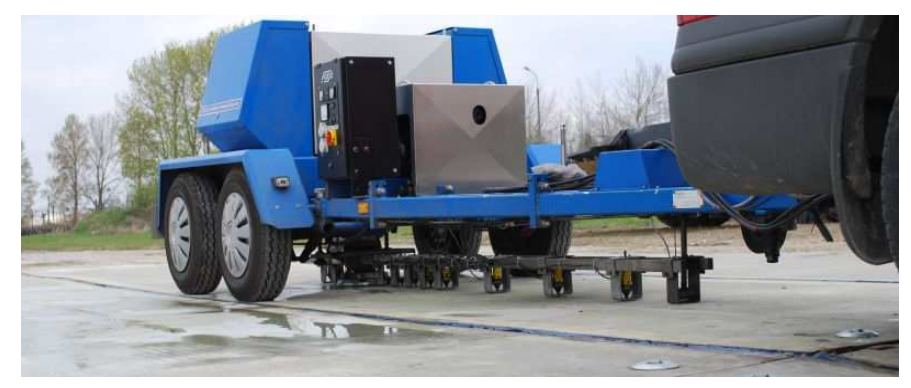

Rys. 3. Badanie nośności układu konstrukcyjnego ugięciomierzem HWD

Fig. 3. Load-bearing capacity tests with the use of HWD 


$$
F=\sum_{j=1}^{k}\left(w_{j}-u_{j}\right)^{2}
$$

gdzie: $w_{j}$ - obliczone ugięcia nawierzchni w odległości $r$ od środka płyty,

$u_{j}$ - pomierzone ugięcia nawierzchni w odległości $r$ od środka płyty,

$k$ - liczba czujników (punktów opisujących czaszę ugięć) równa 9.

Na podstawie przeprowadzonych pomiarów ugięć na pokryciu kompozytowym ELP-1 KRATER, rozłożonym na nowo uformowanym podłożu gruntowym wypełniającym odbudowany krater, uzyskano następującą zależność ugięcia $w$ od współczynnika reakcji podłoża $k$, którą przedstawiono na rys. 4 [4].

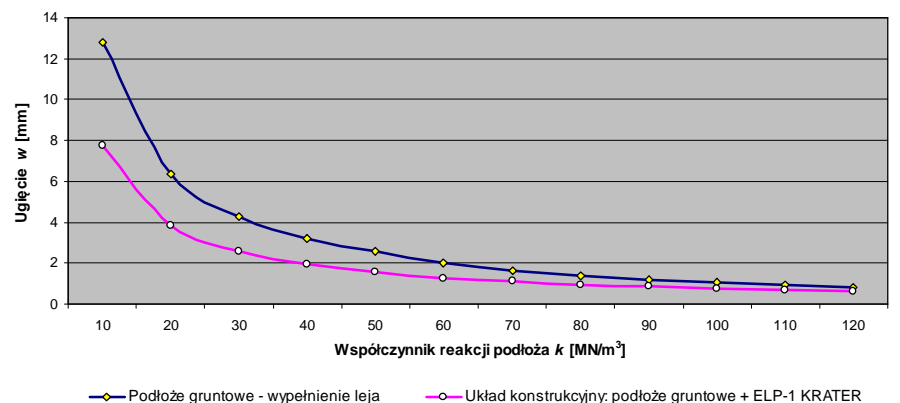

Rys. 4. Zależność ugięcia badanego układu konstrukcyjnego od współczynnika reakcji podłoża

Fig. 4. Mat deflection as a function of the subbase stiffness coefficient

Zastosowanie pokrycia kompozytowego na odbudowanym kraterze powoduje zmniejszenie ugięć całego układu konstrukcyjnego, co jednocześnie wskazuje na zwiększenie jego nośności. Spadek ugięć jest uzależniony od nośności podłoża gruntowego, wyrażonego współczynnikiem reakcji podłoża $k$. Dla $k<70 \mathrm{MN} / \mathrm{m}^{3}$ (podłoże o bardzo niskiej, niskiej i częściowo średniej nośności), pokrycie lotniskowe ELP-1 KRATER ma duży udział w przenoszeniu i przekazywaniu obciążeń, natomiast dla $k \geq 70 \mathrm{MN} / \mathrm{m}^{3}$ (podłoże o średniej i wysokiej nośności) udział pokrycia we współpracy z podłożem jest ograniczony.

\section{Analiza nośności}

Uzyskane wyniki z badań poligonowych posłużyły do przeprowadzenia szczegółowej analizy nośności rozpatrywanego układu konstrukcyjnego pod względem określenia możliwości jego eksploatacji w sytuacjach zagrożenia wojennego przez wybrane typy statków powietrznych, będących na wyposażeniu Sił Zbrojnych RP, tj.: MiG-29, F-16, Su-22, CASA C-295M i C-130E Hercules.

Do analizy nośności przyjęto następujący model obliczeniowy: warstwę kompozytową rozpatrywano jako cienką płytę, zaś podłoże gruntowe jako półprzestrzeń sprężystą. Na podstawie zmierzonych wartości ugięć na badanym 
układzie konstrukcyjnym, wyznaczono czasze ugięć oraz naprężenia. Następnie wyznaczono dopuszczalne, całkowite liczby operacji lotniczych dla przyjętych typów statków powietrznych, które przedstawiono w tabeli 2 [4]. Liczbę dopuszczalnych operacji lotniczych wyznaczono dla określonej liczby powtórzeń obciążenia $N$, którą obliczono dla rozpatrywanego modelu obliczeniowego i analizowanych typów statków powietrznych.

Tabela 2. Wyniki nośności

Table 2. Load-bearing capacity results

\begin{tabular}{|c|c|c|c|c|}
\hline \multicolumn{5}{|c|}{ Dopuszczalna liczba operacji lotniczych } \\
\hline MiG-29 & F-16 & Su-22 & CASA C-295M & Hercules C-130E \\
\hline 32 & 37 & 34 & 48 & 10 \\
\hline
\end{tabular}

Uzyskane wyniki posłużyły do przeprowadzenia analizy wpływu stopnia zagęszczenia podłoża gruntowego stanowiącego wypełnienie krateru (wyrażonego przez współczynnik reakcji podłoża $k$ ) na dopuszczalną ilość operacji lotniczych dla rozważanych typów samolotów. Uzyskane wyniki przedstawiono graficznie na rys. 5 [4].

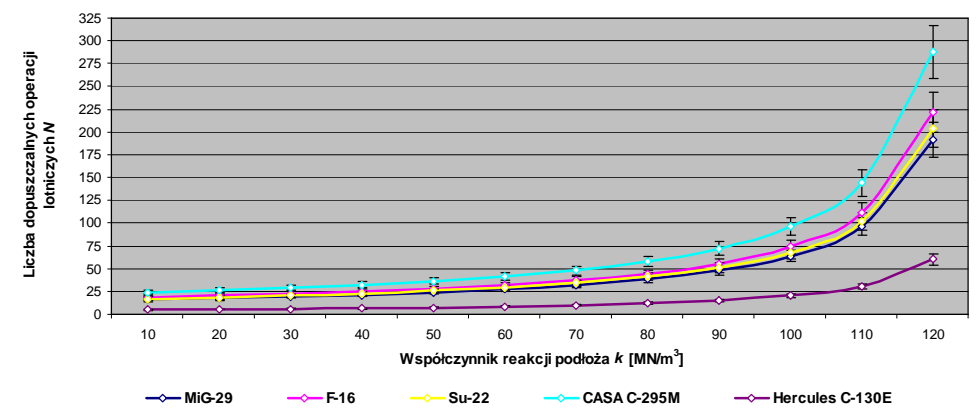

Rys. 5. Liczba dopuszczalnych operacji lotniczych w zależności od współczynnika reakcji $k$

Fig. 5. Number of aircraft operations as a function of the subbase stiffness coefficient

Otrzymane wyniki z przeprowadzonej analizy potwierdziły, że mobilne pokrycie kompozytowe ELP-1 KRATER ułożone na nowo uformowanym podłożu gruntowym w odbudowanym leju spełnia wymagania nośności i zapewnia warunki bezpieczeństwa podczas wykonywania operacji lotniczych dla analizowanych typów samolotów w sytuacjach losowych.

\section{Podsumowanie}

W publikacji przedstawiono wybrane analizy oraz wyniki badań poligonowych, dotyczących nośności mobilnego pokrycia kompozytowego ELP-1 KRATER stosowanego do odbudowy nawierzchni lotniskowych. Zaproponowa- 
no model obliczeniowy dla rozpatrywanego układu konstrukcyjnego w postaci cienkiej płyty (warstwy kompozytowej) na półprzestrzeni sprężystej (podłoże gruntowe). W rezultacie przeprowadzonych badań i analiz uzyskano rozwiązania dotyczące nośności mobilnego pokrycia kompozytowego ELP-1 KRATER stosowanego do odbudowy nawierzchni lotniskowych. Potwierdzono, że układ konstrukcyjny składający się z mobilnego pokrycia kompozytowego i nowo uformowanego podłoża gruntowego, stanowi warstwę nośną przenoszącą bezpiecznie obciążenia pochodzące od statku powietrznego. W kolejnych publikacjach będą sukcesywnie prezentowane wyniki uzyskane w trakcie weryfikacyjnych badań terenowych, zrealizowanych w ramach pracy [4].

\title{
Literatura
}

[1] Nita P.: Określenie wymagań fizyko-mechanicznych dla przenośnych pokryć lotniskowych, ITWL, Warszawa 2001.

[2] Wesołowski M.: Przenośne nawierzchnie lotniskowe, Prace Naukowe Instytutu Technicznego Wojsk Lotniczych, Zeszyt 23, ITWL, Warszawa 2008.

[3] Wesołowski M.: Problemy nośności kompozytowych, mobilnych płyt nawierzchniowych, 56 Konferencja Naukowa Komitetu Inżynierii Lądowej i Wodnej PAN, Krynica 2010.

[4] Wesołowski M.: Nośność mobilnych pokryć kompozytowych stosowanych do odbudowy nawierzchni lotniskowych, Rozprawa doktorska, WAT, Warszawa 2012.

[5] Aerodrome Design Manual, Doc 9157-AN/901, Part 3, Pavements, ICAO, 1983.

\section{TESTS OF THE LOAD-BEARING CAPACITY THE MOBILE COMPOSITE MATS USED TO REPAIR OF AIRFIELD PAVEMENTS}

\begin{abstract}
S u m m a r y
Rapid repair of airfield pavements enables a quick resumption of air operations. Existing technology and methods of airfield pavement reconstruction couldn't meet the stringent time requirements of military operations, that is why mobile, composite airfield mats have been developed. In the paper, operational and maintenance advantages of the elastic, mobile airfield mat ELP-1 KRATER manufactured by Shipyard Żuławy are shown. There is presented the computational model of composite pavement which co-operates with subbase and also shown are the results of field tests, performed by the Air Force Institute of Technology. Moreover, there are presented the results of load-bearing capacity of the composite airfield mat ELP-1 KRATER received during field tests.
\end{abstract}

Keywords: composite airfield pavement, mobile airfield pavement, airfield pavement damage repair, load-bearing capacity of airfield pavements

Przestano do redakcji: 07.06.2016 $r$.

Przyjęto do druku: 30.06.2016 r.

DOI: $10.7862 / \mathrm{rb} .2016 .104$ 